\title{
PENGARUH LAMA EKSTRAKSI MENGGUNAKAN ULTRASONIK TERHADAP AKTIVITAS ANTIOKSIDAN EKSTRAK ETANOL DAUN TEMPUYUNG (Sonchus arvensis L.)
}

\section{Effect of Ultrasonic Extraction Time on Antioxidant Activity of Tempuyung leaf (Sonchus arvensis L.) Ethanol Extract}

\author{
${ }^{1}$ Ni Made Miradita Lestari, ${ }^{2} \mathrm{Ni}$ Made Yusa*, ${ }^{2}$ Komang Ayu Nocianitri \\ ${ }^{1}$ Mahasiswa Program Studi Ilmu dan Teknologi Pangan, Fakultas Teknologi Pertanian, Unud \\ ${ }^{2}$ Dosen Program Studi Ilmu dan Teknologi Pangan, Fakultas Teknologi Pertanian, Unud \\ Kampus Bukit Jimbaran, Badung-Bali
}

\begin{abstract}
This study was conducted to determine the effect of time extraction using ultrasonic method on the antioxidant activity of tempuyung leaves ethanol extract and to find out the exact time to get tempuyung leaves ethanol extract with the highest antioxidant activity. The experimental design used in this study was a completely randomized design with time extraction as a treatment. The treatment consisting of five levels, which is 10 minutes, 20 minutes, 30 minutes, 40 minutes, 50 minutes using ultrasonic method with temperature $45^{\circ} \mathrm{C}$ and frequency $37 \mathrm{kHz}$. All treatments were repeated three times so that they were obtained 15 experimental units. The data obtained were analyzed of variance and if the treatment had significant effect followed by Duncan's Multiple Ring Test. The results showed that the time extraction treatment had a very significant effect $(\mathrm{P}<0.01)$ on yield, total phenol, total flavonoids, total tannin, and antioxidant activity from tempuyung leaves ethanol extract. The best treatment was 30 minutes which produced highest antioxidant activity of $58,60 \%$ with $\mathrm{IC}_{50} 262,82 \mathrm{mg} / \mathrm{L}$ included in the weak category, yield $18,60 \%$, total phenolic $55,05 \mathrm{mg}$ $\mathrm{GAE} / \mathrm{g}$, total flavonoid $38,14 \mathrm{mg} \mathrm{QE} / \mathrm{g}$, total tannin $8,82 \mathrm{mg} \mathrm{TAE} / \mathrm{g}$.
\end{abstract}

Keywords: antioxidant activity, tempuyung leaves, time extraction, ultrasonic

\section{PENDAHULUAN}

Tanaman Tempuyung merupakan tanaman yang dapat tumbuh di tempat dengan ketinggian 50-1650 m dpl dan banyak dijumpai di sekitar persawahan, tepi jalan, dan tebing (Chairul, 2003). Tanaman tempuyung memiliki khasiat yang baik untuk kesehatan manusia. Bagian tanaman tempuyung yang sering dimanfaaatkan untuk kesehatan adalah bagian daun. Daun tempuyung (Sonchus arvensis L.) kurang disukai jika dikonsumsi secara langsung, sehingga masyarakat Bali mengolah daun tempuyung menjadi minuman fungsional berupa loloh (Kusumawati et al., 2014)

Daun tempuyung diketahui memiliki kandungan antioksidan, yang dapat melindungi tubuh dari kerusakan-kerusakan sel akibat radikal bebas. Daun tempuyung memiliki kandungan senyawa bioaktif yaitu tanin, saponin, alkaloid, fenol, dan flavonoid (Ramadhani et al., 2013). Senyawa bioaktif yang terkandung dalam daun tempuyung dapat diperoleh dengan ekstraksi.

Menurut Agoes (2007) ekstraksi merupakan proses pemisahan senyawa bioaktif yang terkandung di dalam suatu bahan dengan menggunakan pelarut. Menurut Ediningsih et al., (2017) etanol 96\% merupakan pelarut yang baik untuk mengekstrak daun tempuyung. Faktor-faktor yang dapat mempengaruhi hasil ekstraksi adalah jenis pelarut, metode ekstraksi dan lama ekstraksi. Metode ekstraksi yang biasa digunakan yaitu maserasi, perkolasi, destilasi uap, soxhletasi dan ultrasonik. Metode ultrasonik adalah metode yang menggunakan gelombang ultrasonik dengan frekuensi lebih besar dari $16 \mathrm{kHz}$. Ekstraksi dengan menggunakan metode ultrasonik memiliki kelebihan dibandingkan ekstraksi

*Korespondesi Penulis :

E-mail: madeyusa@unud.ac.id 
konvensional karena membutuhkan waktu yang singkat, meningkatkan penetrasi dari cairan menuju dinding sel (Sholihah, 2017)

Lama ekstraksi berpengaruh terhadap hasil ekstraksi, terlalu lama atau terlalu singkat waktu ekstraksi dapat mempengaruhi komponen bahan yang terekstrak. Menurut Yuliantari (2017) waktu ekstraksi yang terlalu singkat menyebabkan tidak semua senyawa aktif yang terdapat pada bahan terekstrak, sedangkan waktu ekstraksi yang terlalu lama akan menyebabkan senyawa bioaktif menjadi teroksidasi. Hal ini dapat disebabkan oleh proses kavitasi pada metode ultrasonik yang memecah sel menghasilkan energi yang akan mengakibatkan suhu semakin meningkat, sehingga terjadi oksidasi.

Sekarsari (2019), melaporkan bahwa waktu dan suhu yang optimum untuk ekstraksi daun jambu biji dengan metode ultrasonik menggunakan pelarut etanol $96 \%$ yaitu 20 menit dengan suhu $45^{\circ} \mathrm{C}$. Sementara penelitian Januarti et al., (2017) menghasilkan lama waktu ekstraksi yang optimum untuk ekstraksi daun jati dengan metode ultrasonik menggunakan pelarut etanol $70 \%$ yaitu 30 menit dengan suhu $40^{\circ} \mathrm{C}$. Sampai saat ini belum dilaporkan waktu yang tepat untuk mengekstrak senyawa bioaktif yang terdapat pada daun tempuyung. Oleh sebab itu, perlu dilakukan penelitian tentang lama ekstraksi menggunakan ultrasonik dengan tujuan untuk memperoleh aktivitas antioksidan tertinggi ekstrak ekstrak etanol daun tempuyung.

\section{METODE PENELITIAN}

\section{Tempat dan Waktu}

Penelitian ini dilaksanakan di Laboratorium Pengolahan Pangan, Laboratorium Analisis Pangan, Laboratorium Rekayasa Proses dan Pengendalian Mutu, Fakultas Teknologi Pertanian dan UPT Laboratorium Terpadu Biosains dan Bioteknologi, Universitas Udayana. Penelitian ini dilakukan pada bulan Juli - September 2019.

\section{Bahan dan Alat}

Bahan yang digunakan dalam penelitian ini adalah daun tempuyung (4-8 tangkai dari pucuk yang warnanya hijau muda) yang diperoleh dari desa Tegalalang, Gianyar dan bahan-bahan kimia seperti DPPH (Himedia), reagen Folin-Ciocalteu (merck), etanol 96\% (merck), akuades, standar asam tanat (merck), reagen Follin Denis (merck), standar asam galat (merck), $\mathrm{Na}_{2} \mathrm{CO}_{3}$ (merck), $\mathrm{AlCl}_{3}$, standar kuersetin (sigma), $\mathrm{NaNO}_{2}$ (merck), dan $\mathrm{NaOH}$ (merck).

Alat-alat yang digunakan pada penelitian ini yaitu pisau, oven (Blue $\mathrm{M}$ ), blender (Miyako), ayakan 60 mesh, timbangan analitik (Shimadzu), spatula, alumunium foil, gelas ukur, ultrasonic bath frekuensi $37 \mathrm{kHz}$ (Branson 2200), kertas Whatman No. 1, erlenmeyer, rotary vacuum evaporator (Ika Labortechnik), botol gelap, gelas beaker, spektrofotometer (Genesys 10s Uv-Vis), pipet volume, vortex, tabung reaksi, pipet miko dan water bath (Memmert).

\section{Rancangan Percobaan}

Rancangan yang digunakan pada penelitian ini adalah Rancangan Acak Lengkap (RAL) yang terdiri dari 5 perlakuan lama ekstraksi yaitu : 10 menit, 20 menit, 30 menit, 40 menit dan 50 menit. Perlakuan ini diulang sebanyak tiga kali sehingga diperoleh 15 unit percobaan. Data yang diperoleh dianalisis dengan sidik ragam, apabila perlakuan berpengaruh nyata, maka dilanjutkan dengan uji Duncan's Multiple Range Test (Steel dan Torrie, 1993).

\section{Pelaksanaan Penelitian}

Pelaksanaan penelitian meliputi beberapa tahap yaitu :

1. Persiapan Bahan Baku

Bahan baku berupa daun tempuyung disortasi, dan dicuci hingga bersih menggunakan air. Daun tempuyung kemudian dikeringkan dengan menggunakan oven selama 7 jam dengan suhu $50^{\circ} \mathrm{C}$ hingga kadar air $\leq .10 \%$ (Pada penelitian ini diperoleh kadar air sebesar $7,23 \%$, dengan kriteria daun berwarna hijau pudar dibanding keadaan segar dan mudah dipatahkan). Daun tempuyung kering, diblender hingga halus dan diayak dengan menggunakan ayakan 60 mesh.

2. Ekstraksi Bubuk Daun Tempuyung

Bubuk daun tempuyung sebanyak 10 gram dicampur dengan pelarut etanol $96 \%$ menggunakan perbandingan bahan dengan pelarut sebesar 1:10 (b/v), kemudian diekstraksi dengan menggunakan sonikator selama 10, 20, 30, 40 dan 50 menit. Campuran disaring dengan kertas Whatman No.1 hingga mendapatkan filtrat. Filtrat yang diperoleh diuapkan dengan rotary evaporator sehingga 
diperoleh ekstrak kental daun tempuyung, kemudian dilakukan pengujian sesuai dengan parameter yang diamati.

\section{Parameter yang diamati}

Parameter yang diamati dalam penelitian ini meliputi rendemen yang dihitung berdasarkan berat ekstrak terhadap bubuk (AOAC, 1999), kadar total fenol menggunakan metode spektrofotometri (Sakanaka et al., 2003), kadar total flavonoid menggunakan metode spektrofotometri
(Josipović et al., 2016), kadar total tanin menggunakan metode spektrofotometri (Rajan et al, 2011), aktivitas antioksidan dan $\mathrm{IC}_{50}$ menggunakan metode DPPH (Shah dan Modi 2015).

\section{HASIL DAN PEMBAHASAN}

Hasil analisis rendemen, kadar total fenol, kadar total flavonoid, kadar total tanin, dan aktivitas antioksidan dari ekstrak daun tempuyung dapat dilihat pada Tabel 1.

Tabel 1. Nilai rata-rata rendemen, total fenol, total flavonoid, total tanin, dan aktivitas antioksidan ekstrak daun tempuyung

\begin{tabular}{cccccc}
\hline $\begin{array}{c}\text { Lama } \\
\text { Ekstraksi } \\
(\mathrm{menit})\end{array}$ & $\begin{array}{c}\text { Rendemen } \\
(\%)\end{array}$ & $\begin{array}{c}\text { Total Fenol } \\
(\mathrm{mg} \text { GAE/g) }\end{array}$ & $\begin{array}{c}\text { Total Flavonoid } \\
(\mathrm{mg} \text { QE/g) }\end{array}$ & $\begin{array}{c}\text { Total Tanin } \\
(\mathrm{mg} \mathrm{TAE} / \mathrm{g})\end{array}$ & $\begin{array}{c}\text { Aktivitas } \\
\text { Antioksidan }(\%)\end{array}$ \\
\hline 10 & $11,65 \pm 0,12 \mathrm{a}$ & $35,93 \pm 0,21 \mathrm{~b}$ & $140,97 \pm 1,358 \mathrm{a}$ & $6,00 \pm 0,38 \mathrm{c}$ & $41,95 \pm 0,52 \mathrm{a}$ \\
20 & $12,42 \pm 0,13 \mathrm{a}$ & $50,28 \pm 0,25 \mathrm{~d}$ & $154,08 \pm 0,85 \mathrm{c}$ & $7,13 \pm 0,37 \mathrm{~d}$ & $46,57 \pm 0,52 \mathrm{c}$ \\
30 & $14,22 \pm 1,00 \mathrm{~b}$ & $55,05 \pm 0,05 \mathrm{e}$ & $181,14 \pm 1,37 \mathrm{~d}$ & $8,82 \pm 0,24 \mathrm{e}$ & $58,60 \pm 0,63 \mathrm{~d}$ \\
40 & $15,73 \pm 0,96 \mathrm{c}$ & $42,30 \pm 0,30 \mathrm{c}$ & $150,76 \pm 0,42 \mathrm{~b}$ & $3,01 \pm 0,62 \mathrm{~b}$ & $45,62 \pm 0,39 \mathrm{~b}$ \\
50 & $18,60 \pm 0,73 \mathrm{~d}$ & $34,51 \pm 0,21 \mathrm{a}$ & $151,27 \pm 0,84 \mathrm{~b}$ & $0,92 \pm 0,37 \mathrm{a}$ & $42,36 \pm 0,39 \mathrm{a}$ \\
\hline
\end{tabular}

Keterangan: Huruf yang sama dibelakang nilai rata-rata pada kolom yang sama menunjukkan berbeda tidak nyata $(\mathrm{P}>0,05)$.

\section{Rendemen Ekstrak Daun Tempuyung}

Hasil sidik ragam menunjukan bahwa lama ekstraksi berpengaruh sangat nyata $(\mathrm{P}<$ $0,01)$ terhadap rendemen ekstrak daun tempuyung. Berdasarkan Tabel 1 dapat dilihat bahwa rendemen terendah terdapat pada lama ekstraksi 10 menit yaitu $11,65 \%$ dan berbeda tidak nyata dengan lama ekstraksi 20 menit yaitu $12,42 \%$. Rendemen tertinggi terdapat pada lama ekstraksi 50 menit yaitu $18,60 \%$.

Hasil penelitian menunjukan lama ekstraksi 50 menit menghasilkan rendemen tertinggi ekstrak daun tempuyung. Hal ini dikarenakan semakin lama waktu ekstraksi maka akan semakin meningkatkan rendemen karena kesempatan kontak antara pelarut dan bahan menjadi lebih besar. Pada proses transfer masa pelarut etanol $96 \%$ yang memecah sel pada proses kavitasi tidak hanya melarutkan senyawa bioaktif yang terkandung didalam bahan tetapi komponen selain itu(vitamin, protein, dan mineral) dapat ikut terlarut. Kelarutan bahan tersebut akan terus meningkat hingga pelarut mengalami kejenuhan (Sholihah, 2017).

\section{Kadar Total Fenol Ekstrak Daun Tempuyung}

Hasil sidik ragam menunjukan bahwa lama ekstraksi berpengaruh sangat nyata $(\mathrm{P}<$ $0,01)$ terhadap kadar total fenol ekstrak daun tempuyung. Berdasarkan Tabel 1 dapat dilihat bahwa kadar total fenol terendah terdapat pada lama ekstraksi 50 menit yaitu $34,51 \mathrm{mg}$ $\mathrm{GAE} / \mathrm{g}$. Total fenol tertinggi terdapat pada lama ekstraksi 30 menit yaitu 55,05 $\mathrm{mg}$ $\mathrm{GAE} / \mathrm{g}$.

Hasil penelitian menunjukan bahwa, terjadi peningkatan total fenol pada lama ekstraksi 10 menit sampai dengan 30 menit, kemudian terjadi penurunan total fenol pada lama ekstraksi 40 sampai dengan 50 menit. Hal ini dikarenakan waktu ekstraksi yang lebih lama memungkinkan peningkatan total fenol yang disebabkan oleh kontak gelembung kavitasi memecahkan sel (Wang et al., 2012). Ultrasonik akan ditransmisikan melewati pelarut dengan menginduksikan gelombang suara ke dalam pelarut sehingga molekul akan bergetar. Akibat adanya getaran, struktur dari molekul akan meregang. Selain itu, jarak antar molekul juga akan berubah akibat adanya getaran molekul pada posisi awal. Jika intensitas gelombang ultrasonic terus ditingkatkan, maka akan dicapai suatu kondisi 
maksimum dimana gaya intramolekul tidak dapat lagi menahan struktur molekul seperti keadaan awalnya. Akibatnya molekul itu akan pecah dan terbentuklah lubang. Lubang (kavitasi) ini disebut gelembung kavitasi. Penurunan total fenol dikarenakan proses ekstraksi , sehingga senyawa fenol yang terdapat pada permukaan dan bagian dalam bahan sudah tidak dapat terekstrak lagi (Margaretta et al., 2011).

\section{Kadar Total Flavonoid Esktrak Daun Tempuyung}

Hasil sidik ragam menunjukan bahwa lama ekstraksi berpengaruh sangat nyata $(\mathrm{P}<$ $0,01)$ terhadap kadar total flavonoid ekstrak daun tempuyung. Berdasarkan Tabel 1 dapat dilihat bahwa kadar total flavonoid terendah terdapat pada lama ekstraksi 10 menit yaitu $30,80 \mathrm{mg} \mathrm{QE} / \mathrm{g}$. Kadar total flavonoid tertinggi terdapat pada lama ekstraksi 30 menit yaitu $38,14 \mathrm{mg} \mathrm{QE} / \mathrm{g}$.

Hasil penelitian menunjukan bahwa, terjadi peningkatan total flavonoid pada lama ekstraksi 10 menit sampai dengan 30 menit, kemudian terjadi penurunan total flavonoid pada lama ekstraksi 40 sampai dengan 50 menit. Peningkatan senyawa flavonoid yang terekstrak semakin tinggi, hal ini dikarena semakin lama waktu ekstraksi maka kontak antara bahan dan pelarut akan lebih lama sehingga senyawa flavonoid yang dihasilkan dari proses ekstraksi akan semakin tinggi. Terjadi penurunan senyawa flavonoid, dikarenakan penambahan lama ekstraksi dapat menyebabkan proses kavitasi yang memecah sel menghasilkan energi yang akan mengakibatkan suhu semakin meningkat, sehingga terjadi proses oksidasi yang menyebabkan senyawa flavonoid menjadi berkurang (Bazykina et al.,2002).

\section{Kadar Total Tanin Ekstrak Daun Tempuyung}

Hasil sidik ragam menunjukan bahwa lama ekstraksi berpengaruh sangat nyata $(\mathrm{P}<$ $0,01)$ terhadap kadar total tanin ekstrak daun tempuyung. Berdasarkan Tabel 1 dapat dilihat bahwa kadar total tanin terendah terdapat pada lama ekstraksi 50 menit yaitu 0,92 mg TAE/g. Kadar total tanin tertinggi terdapat pada lama ekstraksi 30 menit yaitu 8,82 mg TAE/g.

Hasil penelitian menunjukan bahwa, terjadi peningkatan total tanin pada lama ekstraksi 10 menit sampai dengan 30 menit, kemudian terjadi penurunan total tanin pada lama ekstraksi 40 sampai dengan 50 menit.
Peningkatan total tanin disebabkan kesempatan untuk bersentuhan antara bahan dan pelarut dengan pelarut akan semakin besar sehingga total tanin yang didapat akan semakin tinggi. Penurunan senyawa tanin dikarenakan proses ekstraksi total tanin pada lama ekstraksi tersebut sudah mencapai titik jenuh, sehingga proses difusi sudah tidak berlangsung (Sekarsari,2019). Salah satu faktor yang mempengaruhi hal ini adalah proses kavitasi pada ekstraksi metode ultrasonik.

\section{Aktivitas Antioksidan dan IC $_{50}$ Ekstrak Daun Tempuyung}

Hasil sidik ragam menunjukan bahwa jenis pelarut berpengaruh sangat nyata $(\mathrm{P}<$ $0,01)$ terhadap aktivitas antioksidan dan $\mathrm{IC}_{50}$ ekstrak daun tempuyung. Berdasarkan Tabel 1 dapat dilihat bahwa aktivitas antioksidan terendah dihasilkan pada perlakuan lama ekstraksi 10 menit yaitu 41,95\% dan berbeda tidak nyata dengan lama ekstraksi 50 menit yaitu $42,36 \%$ sedangkan aktivitas antioksidan tertinggi dihasilkan oleh lama ekstraksi 30 menit yaitu $58,60 \%$.

Hasil penelitian menunjukan bahwa, terjadi peningkatan aktivitas antioksidan pada lama ekstraksi 10 menit sampai dengan 30 menit, kemudian terjadi penurunan aktivitas antioksidan pada lama ekstraksi 40 sampai dengan 50 menit. Aktivitas antioksidan ekstrak daun tempuyung meningkat seiring dengan meningkatnya senyawa yang bersifat antioksidan seperti total flavonoid, total fenol dan total tanin, tetapi setelah mencapai kondisi jenuh, maka aktivitas antioksidan akan menurun selaras dengan penurunan senyawa yang bersifat antioksidan.

Berdasarkan hasil analisis aktivitas antioksidan, lama ekstraksi 30 menit memiliki persentase aktivitas antioksidan tertinggi sehingga perlakuan ini dipilih untuk diuji penentuan $\mathrm{IC}_{0}$.

Berdasarkan analisis regresi liner dapat dilihat pada Gambar 1. diperoleh persamaan yaitu $\mathrm{y}=0,1605 \mathrm{x}+7,8165$ dengan nilai $\mathrm{IC}_{50}$ sebesar $262.82 \mathrm{mg} / \mathrm{L}$. IC IC $_{50}$ menggambarkan besarnya konsentrasi suatu senyawa yang mampu menghambat radikal bebas (DPPH) sebanyak $50 \%$. Jika nilai IC50 semakin kecil maka kemampuan antioksidan semakin besar (Seneviratnhe et al., 2006). Semakin rendah nilai $\mathrm{IC}_{50}$ maka semakin besar kemampuan antioksidannya. Menurut Blois (1958) suatu senyawa memiliki aktivitas antioksidan yang 
sangat kuat apabila memiliki nilai $\mathrm{IC}_{50}<50$ $\mathrm{mg} / \mathrm{L}$, sehingga ekstrak daun tempuyung dalam penelitian ini termasuk dalam kategori lemah.

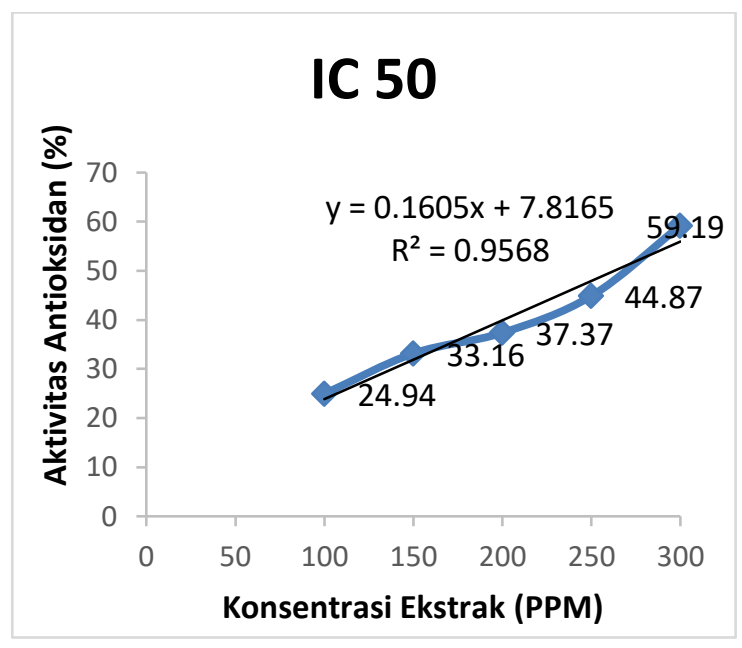

Gambar 1. Grafik hubungan konsentrasi ekstrak dengan aktivitas antioksidan

\section{KESIMPULAN DAN SARAN}

\section{Kesimpulan}

1. Lama ekstraksi berpengaruh sangat nyata terhadap rendemen, total fenol, total flavonoid, total tanin, dan aktivitas antioksidan dari ekstrak etanol daun tempuyung.

2. Lama ekstraksi optimum yang dapat digunakan untuk mengekstrak daun tempuyung adalah 30 menit dengan total fenol sebesar 55,05 mg GAE/g, total flavonoid sebesar $181,14 \mathrm{mg}$ QE/g, total tanin sebesar $8,82 \mathrm{mg}$ TAE/g dan aktivitas antioksidan sebesar 58,60\% dengan nilai $\mathrm{IC}_{50}$ sebesar 262,82 mg/L.

\section{Saran}

Perlu dilakukan penelitian lebih lanjut tentang metode ekstraksi yang tepat untuk mengekstrak daun tempuyung sehingga dapat dimanfaatkan sebagai sumber aktivitas antioksidan tertinggi,

\section{DAFTAR PUSTAKA}

Agoes, G. 2007. Teknologi Bahan Alam. ITB Press, Bandung.

AOAC. 1990. Official Method of Analysis of Association Official Agriculture Chemist. Washington DC.
Bazykina,N.I., A. N. Nikolaevskii, T. A. Filippenko, V. G. Kaloerova. 2002. Optmization of conditions for the extract ion of natural antioxidants from raw plant materials. Pharmaceutical Chemistry Journal 36(2):46-49. DOI: 10.1023/A:1016024300843.

Blois, M.S. 1958. Antioxidant determinations by the use of a stable free radical. J. Nature, $181: 1199-1200$.

Chairul, S. M., R., Sumarny, dan Chairul. 2003. Aktivitas Antioksidan Ekstrak Air Daun Tempuyung (Sonchus arvensis L.) Secara In-vitro. Majalah Farmasi Indonesia. 14 (4): 208-215.

Ediningsih, H., Nurhayati dan R. Rubiana. 2017. Uji Aktivitas Antioksidan Ekstrak Daun Tempuyung (Sonchus Arvensis L.). Balai Penelitian Tanaman Rempah dan Obat. Bogor.

Januarti , I.B., A. Santoso, dan A, S.Razak. 2017. Ekstraksi Senyawa Flavonoid Daun Jati (Tectona Grandis L.) Dengan Metode Ultrasonik (Kajian Rasio Bahan : Pelarut Dan Lama Ekstraksi). Fakultas Kedokteran. Universitas Islam Sultan Agung. Semarang

Josipovic, A., R. Sudar, A. Sudaric, V. Jurkovic, M.M. Kocar dan A.M. Kulundzic. 2016. Total phenolic and total flavonoid content variability of soybean genotypes in eastern croatia. Croatia Journal Food Science Technology. 8(2): 60-65

Kusumawati, I.G.A.W, I.P. Darmawijaya, dan I.B.A. Yogeswara. 2014. Potensi antioksidan loloh tempuyung (Sonchus arvensis L.) sebagai minuman fungsional. Universitas Dhyana Pura Bali. ResearchGate. 1-8.

Margaretta, S., S.D. Hanyani, N. Indraswati dan H. Hindarso. 2011. Ekstraksi senyawa phenolic Pandanus amaryllifolius Roxb sebagai antioksidan alami. Jurnal Widya Teknik. 10(1):2130.

Rajan, S., S. Mahalakshmi., V Deepa., K. Sathya., S. Shajitha., dan T. 
Thirunalasundari. 2011. Antioxidant potentials of punica granatum fruit rind extracts. International Journal of Pharmacy and Pharmaceutical Sciences 3: 82-88.

Ramadhani, R.A, D. Kusrini, dan E. Fachriyah. 2013. Isolasi, identifikasi dan uji antioksidan senyawa flavonoid dari ekstrak etil asetat daun tempuyung (Sonchus arvensis L.). Chem Info. 1 (1) : 247-255.

Sakanaka, S. Tachibana, Y. Okad dan Yuki. 2005. Preparation and antioxiant properties of extracts of Japanese persimo leaf tea (kakinocha-cha). Food Chemistry 89: 569-575.

Sekarsari, S., ., I W. R. Widarta., dan A. A. G. N. A Jambe. 2019. Pengaruh Suhu Dan Waktu Ekstraksi Dengan Gelombang Ultrasonik Terhadap Aktivitas Antioksidan Ekstrak Daun Jambu Biji (Psidium Guajava L.) Scientific Journal of Food Technology , Vol. 8, No. 3, 267-277.

Senevirathne, M., S. Kim, N. Siriwardhana, J. Ha, K. Lee dan Y. Jeon. 2006 Antioxidant potential of Ecklonia cava on reactive oxygen species scavenging, metal chelating, reducing power and lipid peroxidation inhibition. Food Science and Technology International. 12: 27-38.

Shah, P dan H.A. Modi. 2015. Comparative study of DPPH, ABTS and FRAP assays for determination of antioxidant activity. International Journal for Research in Applied Science and Engineering Technology. 3(6): 636-64

Sholihah, M. 2016. Ultrasonic-Assisted Extraction Antioksidan Dari Kulit Manggis. Tesis: Sekolah Pascasarjana Institut Pertanian Bogor, Bogor.

Widarta, I. W. R., dan I. W. Arnata. 2016. Ekstraksi Komponen Bioaktif Daun Alpukat dengan Bantuan Ultrasonik pada Berbagai Jenis dan Konsentrasi Pelarut. AGRITECH, Vol. 37 No. 2, Hal. 148-157.

Yuliantari, N. W. A., I W. R. Widarta,. dan I. D. G. M. Permana. 2017. Pengaruh
Suhu dan Waktu Ekstraksi Terhadap Kandungan Flavonoid dan Aktivitas Antioksidan Daun Sirsak (Annona muricata L.) Menggunakan Ultrasonik. Scientific Journal of Food Technology. 4(1): 35-42. 